\title{
Impact of the Age of Particulates on the Bioremediation of Crude Oil Polluted Soil
}

\author{
${ }^{1}$ Onakughotor Ejiro Dennis, ${ }^{2}$ Aguele Precious Osatohamhen \\ ${ }^{I}$ Petroleum And Natural Gas Processing Department Petroleum Training Institute \\ Effurun, Delta State, Nigeria.
}

\begin{abstract}
This study was conducted to investigate the effect of the age of poultry manure particulate on the bioremediation process of crude oil contaminated soil. pH, Total Hydrocarbon Content(THC) and Total Microbial Count(TMC) were measured to monitor the performance of four soil samples weighing $4 \mathrm{~kg}$ each. These samples were polluted with $0.2 \mathrm{~kg}$ of crude oil per kilogram soil; and amended with particulates and fertilizer of $0.2 \mathrm{~kg}$ and $0.08 \mathrm{~kg}$ per kilogram soil respectively. The age of particulate used in each sample varied in no particular order from 3days to 126 days. The study lasted 8weeks. Results obtained showed 99.17 $\%(84.10-0.70 \mathrm{mg} / \mathrm{kg}), \quad 98.07 \%(82.90-1.60 \mathrm{mg} / \mathrm{kg}), \quad 98.69 \%(84.10-1.10 \mathrm{mg} / \mathrm{kg})$ and $97.72 \%(83.40-1.90 \mathrm{mg} / \mathrm{kg})$ drop in Total Hydrocarbon Content for samples A,B,C and D respectively.THC for all samples fell below the FEPA limit of $10 \mathrm{mg} / \mathrm{l}$ on closure. Sample $A$ had the highest TMC 3.0x10 $\mathrm{cfu} / \mathrm{g}$; while D had the least, $2.2 \times 10^{6} \mathrm{cfu} / \mathrm{g}$. The $\mathrm{pH}$ of all samples at the end of the study (6.5-6.9) fell within the range specified by FEPA (69). The overall data suggested that lower aged poultry manure particulates did best and be employed in the amendment of crude oil polluted soil.
\end{abstract}

\section{Introduction}

Over the years, a supposed natural resource, the activities of Oil and Gas Industry has turned out to be a threat, to the environment, when spillage into soil or water occurs. Spilled crude-oil is denser than water, thus reduces and restricts permeability; also it contains hydrocarbons which fill the soil pores and expel water and air, thereby depriving the plant roots the much needed water and air (Brian, 1977). Depending on the degree of pollution, the oil polluted soil may remain unsuitable for use for months or even years (Nwandinigwe and Onyeidu, 2012).

Oil spillage has caused untold hardship on those residing in areas where this natural resource is in abundance, as it has deprived them of portable water; being that the surface and ground water gets contaminated when oil spills. It has also deprived most of them of their economic source of livelihood: the farmers and fishermen especially.

Due to high demand on land and water, it is imperative that the soil and water bodies affected be rehabilated in time for use; therefore natural methods like bush fallowing (for soil), cannot always be relied on. This has given rise to several techniques of remediation. This work focuses on the remediation of polluted soil.

Amidst the various techniques that can be utilised in replenishing soil nutrients, as has been developed over the years, bioremediation seems to be most thriving. This is because, unlike the physiochemical, and other methods of remediation, there is no destruction of site material, or its natural existing flora and fauna before achieving complete degradation of the organic pollutants from the crude oil (Timmis and Pieper, 1999).

Bioremediation involves degrading contaminants through the use of naturally occurring microorganisms and microbes. Crude oil in a sense is a natural product formed from high temperature anaerobic conversion of biomass, and all natural organic compounds degrade, thus it could be subject to bioremediation (Yehuda C., 2002). The two approaches to bioremediation are Bioaugumentation and Biostimulation.

Bioaugumentation is the addition of the bacterial culture to the contaminated soil. Biostimulation is adding microbial nutrients needed to increase microbial activities of indigenous microbial flora and fauna to a contaminated soil (Odu et al., 2005).

Poultry droppings act as a biostimulant, like the N.P.K. 15.15.15., ferrous sulphate as well as other organic and inorganic fertilizers, under ambient conditions, tend to reduce the hydrocarbon content of contaminated soil, thus leading to increase in soil fertility.

\section{Scope Of Study}

- Collection of samples (soil, crude oil, poultry droppings, N.P.K fertilizer).

- Contamination of soil with crude oil.

- Addition of amendments for remediation to occur.

- Collection of samples for laboratory analysis weekly, for 8 weeks.

- Evaluating the performance of the process based on the results obtained from the laboratory analysis. 


\section{Relevance Of Study}

The petroleum industry is an economic backbone to most countries today, hence its production, which is continuous will be for a very long time. In view of this, there is the need to investigate into cheap and environmentally friendly methods of remediating soils affected by the accident (spillage) that comes along with the production, transportation, etc of the crude oil and its products; which in the long run is inevitable.

Bioremediation of contaminated soil with poultry manure aids in utilizing such waste and providing an environmentally acceptable way of disposal. It will also help boost economic activities as those utilizing the soil for agricultural purposes will not be deprived of it. Community hostilities that could hamper economic activities of the petroleum industry are minimized. Most importantly, it safeguards the environment; being that it solves the problem of land pollution in a natural and environmentally friendly way.

\section{Crude Oil}

Crude oil, petroleum, fossil fuel, black gold and other various names by which it is known is a naturally occurring, dark, viscous liquid found under the ground. It is a non-renewable source of energy. Crude oil is a dark, sticky naturally-occurring liquid, classified scientifically as a hydrocarbon found in certain rock formations in the earth, highly flammable and can be burned to create energy, may or may not contain nonmetallic elements such as oxygen and sulphur (OPEC).

Crude oil is a complex biodegradable substance containing a large variety of hydrocarbons such as straight, branched and cyclic aliphatics, aromatic and heterocyclic compounds (Obahiagbon et al., 2009).

\subsection{Composition Of Crude Oil.}

Crude oil is composed elementarily of carbon, hydrogen, sulphur and nitrogen. It is a complex mixture of several polycyclic aromatic compounds and other hydrocarbons (Domask, 1984).Metals, such as vanadium, nickel, chromium are sometimes present in crude oil as shown in the table below. The hydrocarbons in crude oil are in three classes; parraffins, naphthenes and aromatics.

Table 1: Elementary Composition of Crude Oil.

\begin{tabular}{|l|l|}
\hline Element & Percent by weight \\
\hline Carbon & $84-87$ \\
\hline Hydrogen & $11-14$ \\
\hline Sulphur & $0-3$ \\
\hline Nitrogen & $0-0.6$ \\
\hline
\end{tabular}

Source: Gary and Handwerk, (2001).

\subsection{Physical Properties Of Crude Oil.}

There are certain properties that are most times used to classify crude oil. They sometimes serve as basis for tests (Gruse and Stevens, 1960). These properties include: API Gravity, Sulphurontent, reidvapour pressure, pour point $\left({ }^{\circ} \mathrm{F}\right)$, metal content, carbon residue.

\section{3products Obtained From Crude Oil And Their Uses.}

There are over 2000 products obtained from crude oil, according to a survey carried out by the American Petroleum Institute, (API) (API bulletin, 1958). Over 4000 petrochemical products can be obtained from crude oil (OPEC). These products are obtained during the fractional distillation of the petroleum, and at different temperatures, i.e. the desired boiling points, they are withdrawn. The uses of these products range from providing heat energy for transport, to cooking, etc, as well as lubricating, as chemical solvents, pigments, etc. Some of the petroleum products produced in Nigeria include gasoline, diesel, lube oil, asphalt, kerosene and other jet fuels, methane, ethane, butane, etc.

Table 2: Some distillation components of Nigerian Brass crude oil

\begin{tabular}{|c|c|c|}
\hline Distillation fraction & Composition (\%) & Chain length \\
\hline Gasoline & 11.2 & $\mathrm{C}_{4}-\mathrm{C}_{10}$ \\
\hline Naphtha & 18.1 & $\mathrm{C}_{4}-\mathrm{C}_{10}$ \\
\hline Kerosene & 16.9 & $\mathrm{C}_{10}-\mathrm{C}_{20}$ \\
\hline Gas oil & 15.7 & $\mathrm{C}_{15}-\mathrm{C}_{40}$ \\
\hline Heavy gas & 25.8 & $\mathrm{C}_{40}$ and above \\
\hline
\end{tabular}

Source: Adams P.J., (1996).

\subsection{Oil Spillage}


Crude oil could be introduced into the soil accidentally, operationally or intentionally, during production, while transporting, processing, released as waste (Obahiagbon and Audu, 2002). In most cases, it is introduced accidentally into soil and water bodies during drilling operations, production processes, when pipelines are corroded or vandalised, leakage from storage tanks, or certain other reasons caused by general laxity on the part of petroleum companies.

Table 3: Causes of Oil Spill and the Percentage

\begin{tabular}{|l|l|}
\hline Cause & Percent (\%) \\
\hline Corrosion & 50 \\
\hline Sabotage & 28 \\
\hline Production operations & 21 \\
\hline Non-functional production equipment & 1 \\
\hline
\end{tabular}

Source: Nwiloand Badejo . (2001).

\subsection{Effect Of Crude Oil To The Soil}

It is a known fact that petroleum hydrocarbon adversely affects soil ecology and fertility. Crude oil changes the physico-chemical properties of soil. It increases the level of toxins, such as zinc and iron in the soil (Udo and Fayemi, 1975) and reduces the amount of nutrients available. There is high accumulation of aluminium and manganese ions, which are toxic to plant growth, due to the anaerobic condition in the soil,the water logging and acid metabolites created by the crude oil (Onwurah et al., 2007). Furthermore, there is reduction in the amount of oxygen diffused to the root system if the oil is stranded on the plant shoot, thus affecting the soil indirectly. Physical properties such as soil moisture, water holding capacity, porosity, $\mathrm{pH}$ and exchangeable phosphorus reduce, while soil nitrogen, organic carbon content and exchangeable potassium increase (Debojit et al.,2011). The $\mathrm{pH}$ of the polluted soil being more acidic is as a result of the formation of toxic acids in the spilled oil (Udo and Fayemi, 1975). The low soil water contents of the crude oil contaminated soil could be due to reduce soil moisture recharge caused by hydrophobic nature of crude oil contaminated soil (Baruah and Das, 1994).

Crude oil may also slow down the rate of seed germination, reduce height, stem density, photosynthetic rate and biomass, most times resulting in complete mortality (Tanee and Akonye, 2009). A possible reasons for inhibition of germination in crude oil contaminated soil is insufficient aeration due to decrease in air filled space and increased demand of oxygen by oil decomposing microorganisms (Clarkson et al., 1980).

It causes morphological aberrations, reduction in biomass, to cellular and stomatal abnormalities (Wallace 1951). A study carried out in Asaba, Delta State, showed that crude oil contamination on the soil significantly reduces the biomass accumulation in Jatrophacurcas seedlings (Agbogidi, 2011). Another research in Calabar by Ekpo et al., 2012 showed that crude oil pollution reduces the germination and growth of the soybean plant, especially at higher pollution rates.Black (1957) reported the inhibition of root growth due to acidity, which was caused by crude oil contamination. He also demonstrated that growth and development of plants are adversely affected by crude oil pollution, ranging from wilting, chlorosis, tissue and cell maceration, blotching and the collapses of marginal necrotic spots, which have eventually resulted in the death of plants.

Fresh crude oil has a coagulatory effect on the soil, it binds the soil particles into a water impregnable soil block thus, seriously impairing water drainage and oxygen diffusion and seeds fail to germinate . Oil spillage that occurred in Nigeria on dry land between 1978 and 1979, grossly affected farmlands where crops like rice, yam, plantain, cassava were cultivated (Onwurah, 1999). The depletion of the vegetative cover and mangrove ecosystem of the Niger Delta area of Nigeria is as a result of the oil spillages that have occurred in the area over the years (Odu, 1987). Hence, crude oil in soil makes the soil condition unsatisfactory for plant growth In view of this methods have to be developed to make the soil suitable for farming again, as well as water bodies conducive for aquatic life.

\subsection{Soil Remediation}

Several attempts have been made to correct or improve the condition of the soil. Various methods have thus far been developed, they includes excavation, vapour extraction, stabilization and solidification, containment in secured landfills, solvent extraction, thermal desorption, incineration and vitrification (US EPA, 1988). Although these processes have been proven capable of treating the soil, several regulatory requirements also have to be satisfied before it could be used on the field.

It was classed as physical/chemical treatment, heating treatment and bio-treatment, others (land fill and natural purification). Remediation could be classified as mechanical, physical, chemical and biological (Tanee and Albert, 2011).

\subsubsection{Bioremediation}


The first thing that comes to mind at this word "bio and remediation", is correcting a situation with living things. Thus, one could say bioremediation is the use of microorganism metabolism to remove pollutants. It is a technology that exploits the abilities of microorganisms and other natural habitat of the biosphere to improve environmental quality for all species, including man (Onwurah et al., 2007). It could also be defined as a process that utilizes microorganisms or their enzymes to restore a contaminated environment to its original state. It uses the natural ability of microorganisms to reduce the concentration and toxicity of various chemical substances.

\subsubsection{Bioremediation Of Crude Oil Contaminated Soil.}

As stated in the previous section, bioremediation can be used for the cleanup of crude oil contaminated soil. Crude oil is natural product, thus it is susceptible to degradation by naturally occurring microflora (Okeimen and Okeimen, 2005), and like it is generally known, the performance of plants in soils not suitable for their growth is enhanced when the soil is augmented with manure.

This clean up of the contaminated soil can be done in two methods, namely in-situ and ex-situ bioremediation.

The in-situ bioremediation process has the advantage of being carried out without disturbing normal site operations, since there is no need for excavation. The treatment of the contaminated soil is done at the site of contamination.

Ex-situ bioremediation involves the physical removal of the contaminated material into large contained spaces where they are treated (Boopathy, 2000).

There are two types of the bioremediation of crude oil contaminated soil; the microbial remediation and phytoremediation (Tang et al., 2010).

Phytoremediation utilizes plant to degrade, stabilize and remove soil contaminants. These plants decontaminate polluted soil through three mechanisms

- $\quad$ direct uptake of petroleum hydrocarbons into their tissues

- Release of enzymes and exudates that stimulate the activity of hydrocarbonoclastic microbes.

- direct biochemical transformation (enzymes) of petroleum hydrocarbons

(Schnoor et al., 1995).

Microbial remediation involves correcting the soil condition via the activities of microorganisms. Biostimulation or bioaugumentation, or intrinsic approaches could be used in this regard.

- Bioaugmentation: It involves the addition of adapted microbial hydrocarbon degraders. These new microbes help improve the ability of the naturally occurring microbes to degrade hydrocarbons. It has the advantage of greater respiration rate, thus shorter bioremediation period and most times better result (Benyahia F. et al., 2005).

- Intrinsic bioremediation (natural attenuation): This is an unassisted method. Bacteria are allowed to grow in the contaminated soil without interference of any type. Only regular monitoring is done (Boopathy, 2000).

- Biostimulation: This is the most widely used method; it involves the addition of several nutrients, capable of making up for the lost inorganic nutrients caused by the contamination with hydrocarbons. Organic, inorganic fertilizers, such as N-P-K or oleophilic fertilizers could be used for this purpose of stimulating indigenous microbial population in contaminated soils. These nutrients help increase the bioavailability in the medium. It can also be achieved by addition and aeration. It is the most commonly used method for insitu bioremediation (Baba M.T. et al., 1998)

\subsection{Poultry Manure:}

The nutrient composition of poultry manure varies depending on the type of bird, feed, litter and proportion of litter to droppings. This manure is usually a mixture of the poultry droppings, beddings or litters (they are usually wood chips, wheat straw, sawdust, rice and peanut hulls, paper, etc), feathers and wasted feed.

Table 4: Elements Contained Poultry Manure

\begin{tabular}{|c|c|}
\hline Element & Mean value (g/kg material) \\
\hline Water & 657 \\
\hline Total C & 289 \\
\hline Total N & 46 \\
\hline $\mathrm{NH}_{4}-\mathrm{N}$ & 14 \\
\hline $\mathrm{NO}_{3}-\mathrm{N}$ & 0.4 \\
\hline $\mathrm{P}$ & 21 \\
\hline $\mathrm{K}$ & 21 \\
\hline $\mathrm{Cl}$ & 24.5 \\
\hline $\mathrm{Ca}$ & 39 \\
\hline $\mathrm{Mg}$ & 5 \\
\hline $\mathrm{Na}$ & 4.2 \\
\hline
\end{tabular}


Source: Edwards and Daniel, (1992).

\begin{tabular}{|c|c|}
\hline $\mathrm{Cu}$ & 0.304 \\
\hline $\mathrm{Fe}$ & 0.320 \\
\hline $\mathrm{Mn}$ & 0.053 \\
\hline $\mathrm{Zn}$ & 0.354 \\
\hline $\mathrm{As}$ & 0.029 \\
\hline
\end{tabular}

\section{Results And Discussion}

\section{$5.1 \mathrm{pH}$}

Table 5: pH Values over Time for the Bioremediation of Crude Oil Contaminated Soil with Particulates of Different Ages.

\begin{tabular}{|l|l|l|l|l|l|l|l|l|l|l|}
\hline \multirow{2}{*}{ SAMPLE } & AGE OF & \multicolumn{6}{|c|}{ TIME (WEEKS) } \\
\cline { 3 - 12 } & SAMPLE(DAYS) & 0 & 1 & 2 & 3 & 4 & 5 & 6 & 7 & 8 \\
\hline $\mathrm{A}$ & 3 & 5.9 & 5.7 & 5.8 & 5.9 & 6.2 & 6.3 & 6.5 & 6.5 & 6.6 \\
\hline $\mathrm{B}$ & 28 & 6.2 & 6.3 & 6.1 & 5.9 & 6.0 & 6.1 & 6.2 & 6.4 & 6.5 \\
\hline $\mathrm{C}$ & 42 & 6.3 & 6.1 & 5.9 & 6.1 & 6.2 & 6.4 & 6.4 & 6.5 & 6.7 \\
\hline $\mathrm{D}$ & 126 & 6.1 & 6.3 & 6.2 & 6.4 & 6.5 & 6.7 & 6.6 & 6.7 & 6.9 \\
\hline
\end{tabular}

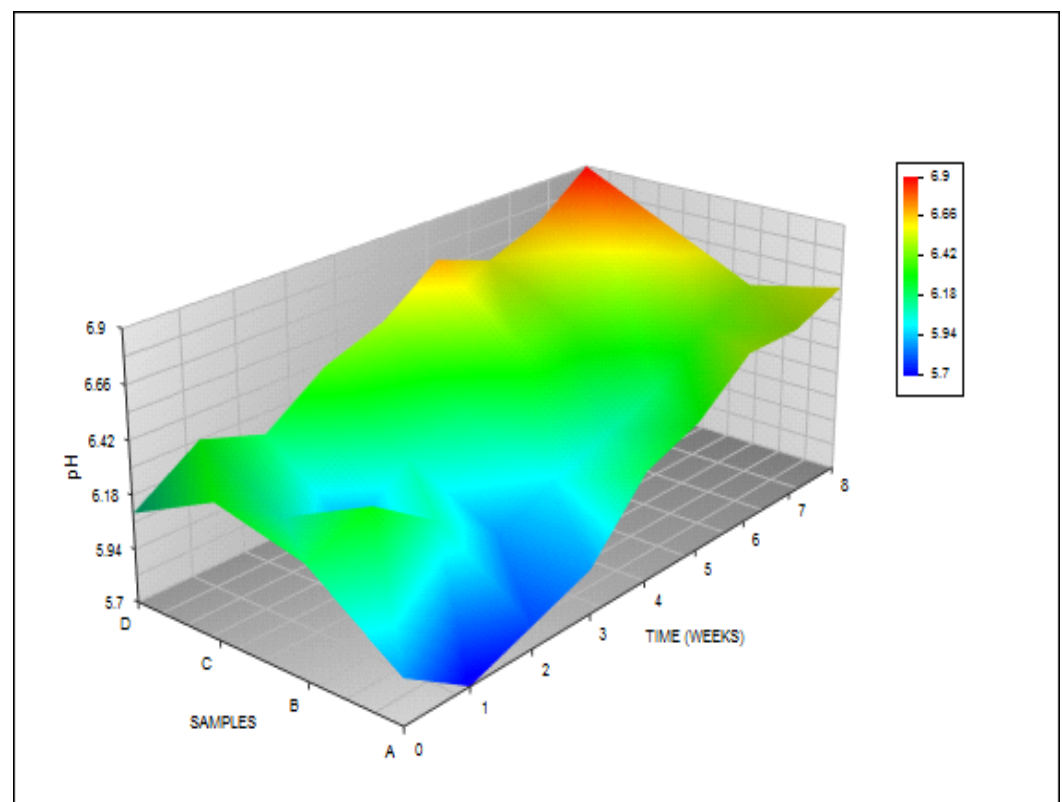

Figure 1: variation of soil $\mathrm{pH}$ with Bioremediation Time and Particulate age.

It was observed from figure 1, a plot of $\mathrm{pH}$ as a function of bioremediation time and age of particulates that $\mathrm{pH}$ progressively increased with time. The same trend was observed with respect to the age of particles. However, at the start of bioremediation, it could be observed that there was a slight fluctuation in $\mathrm{pH}$ with particulate age. On pollution, i.e. week 0; all samples were slightly acidic (5.9-6.3). Over time, an averagely increasing trend was noticed. This suggests that the amendments tended to decrease the acidity of the soil samples. This decrement could have resulted from the biodegradation of crude oil by bacteria under anaerobic conditions in the soil pores (Essien and John, 2010); as well as the ability of crude oil to act as a buffer for the polluted soil (Ellis et al., 1961).This trend was also noticed by Ebere et al., (2011), where pH increased averagely from 5.21 to10.1for crude oil polluted soil remediated with NPK, saw dust and poultry manure. Essien and John (2010), reported similar results when loamy soil polluted with crude oil was reclaimed with chemical degreasers and detergents, the $\mathrm{pH}$ increased from 4.5 to 5.8 .

Enejeet.al., (2012) also reported a decrease in $\mathrm{pH}$ acidity when the effect of poultry manure and Calapoigoniummucunoides on crude oil contaminated soil was studied in a completely random design. Samples were collected at different depths, polluted by $30 \mathrm{mg} / 1$ and water $50 \%$ of retention capacity was added. Amendments were added, kept in a green house and allowed to stand for three weeks. The $\mathrm{pH}$ of samples amended with poultry increased from 4.85 to 6.83

In this work, samples A and B had same $\mathrm{pH}$ in week 3, after which a progressively increasing trend is observed for both, with $\mathrm{A}$ having a higher $\mathrm{pH}$ at the end of the experiment. Sample $\mathrm{C}$ (containing poultry manure aged 42 days) had a higher $\mathrm{pH}$ value than samples $\mathrm{A}$ and $\mathrm{B}$ at the end of the process; its $\mathrm{pH}$ initially decreased from 6.3 in week 0 to 6.1 in week 1 after amendments were added. From thence, $\mathrm{C}$ showed a gradual increase in $\mathrm{pH}$ throughout the experiment. Similarly, sample D, which contained the oldest poultry manure 
particles of 126days had the highest $\mathrm{pH}$ value throughout the experiment, except for the first week, despite fluctuations in the trend within weeks. The decrease in $\mathrm{pH}$ of sample $\mathrm{B}$ as compared to the increasing trend of $\mathrm{pH}$ with age of particles at the end of the remediation period could be attributed to climatic conditions. Salt concentration is said to increase as the soil dries, thus under such conditions, soluble cations are replaced by hydronium $\left(\mathrm{H}_{3} 0^{+}\right)$ions (USDA, 2004), hence sample B which received more heat from the sun as compared to other samples returned the least increase in $\mathrm{pH}$. The $\mathrm{pH}$ throughout the 8 weeks of bioremediation for all four samples was within the range optimum for plant growth (5.5-7) (Ronen, 2007), as well as 6-9 as required by FEPA. This indicates an effective bioremediation process.

\subsection{Total Hydrocarbon Content}

Table 6: Total Hydrocarbon Content of Crude Oil Contaminated Soil Bioremediated with Poultry Manure of Different Ages

\begin{tabular}{|c|c|c|c|c|c|c|c|c|c|c|}
\hline SAMPLE & AGE OF & \multicolumn{9}{|c|}{ TIME (WEEKS) } \\
\cline { 3 - 11 } & SAMPLE(DAYS) & 0 & 1 & 2 & 3 & 4 & 5 & 6 & 7 & 8 \\
\hline A & 3 & 84.10 & 63.90 & 48.90 & 34.80 & 25.30 & 17.40 & 10.20 & 4.30 & 0.70 \\
\hline B & 28 & 82.90 & 65.80 & 49.20 & 36.80 & 26.70 & 18.90 & 11.10 & 5.40 & 1.60 \\
\hline C & 42 & 84.10 & 63.50 & 48.20 & 33.90 & 25.70 & 18.30 & 11.40 & 5.20 & 1.10 \\
\hline D & 126 & 83.40 & 61.80 & 47.30 & 34.20 & 26.40 & 19.90 & 12.10 & 6.60 & 1.90 \\
\hline
\end{tabular}

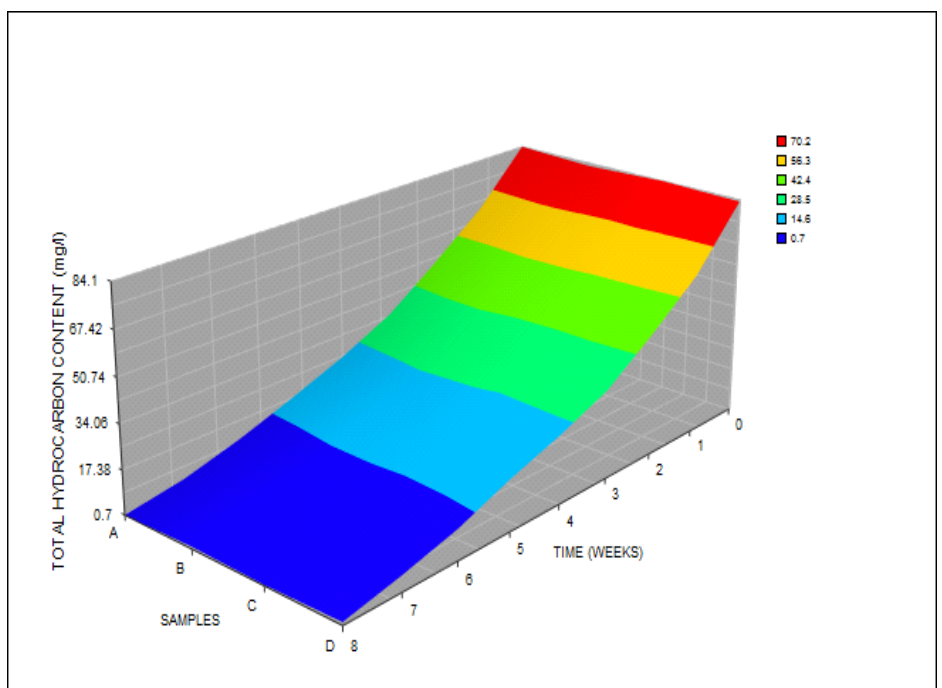

Figure 2: Variation of Total Hydrocarbon Content with Time And Age of Particles during the Bioremediation Process.

The variation of the Total Hydrocarbon Content (THC) with age of manure particulate and bioremediation time is presented in figure 2. It was observed generally that THC decreased with time of bioremediation, but increased with age of particulates. During the early period of remediation, precisely weeks 1-3; samples C and D retuned better results, being that their THC values were slightly lower than those of A and B for that period. However from the following week, (4), there was a change as samples A and B returned THC of lower values than C and D. No particular order for the decrease in Total Hydrocarbon Content for each individual week with respect to the age of the particles could be initially inferred as there was no noticeable trend till the last two weeks of the experiment.

\section{Table 7: Percentage Reduction in Total Hydrocarbon Content (THC) of Soil Bioremediated with Poultry} Manure Particulates of Different Ages.

\begin{tabular}{|c|c|}
\hline Sample & THC reduction (\%) \\
\hline A & 99.17 \\
\hline B & 98.07 \\
\hline C & 98.69 \\
\hline D & 97.72 \\
\hline
\end{tabular}

Table 7 shows a summary of the result presented in table 8 . It shows the percentage decrease in THC of the four samples. From the table it was deduced that the younger the particulates the better as sample A ( 3 days) had the highest percentage reduction and D (126 days) had the least percentage reduction value, since the major aim of the bioremediation process is to reduce the hydrocarbon content to levels recognised as safe by regulatory bodies(Obahiagbon et.al., 2009). This conforms with the results obtained by Tanee and Albert, 
(2011); showing a decrease in Total Hydrocarbon Content in a crude oil polluted soil amended with saw dust,(similar to sample A) by $75 \%$.

Ayotamuno et.al.,(2013) in a study where petroleum contaminated soil was remediated with plantain stem and poultry feaces, observed a decrease in Total Hydrocarbon Content as well. 400g of soil was polluted with 0.25 litres of crude oil, treatments of different quantities were added. The samples containing the poultry dung performed best with the total petroleum hydrocarbon reducing from $17,284 \mathrm{mg} / \mathrm{kg}$ to $1,186 \mathrm{mg} / \mathrm{kg}$ at the end of the two months.

A similar decrease in total petroleum hydrocarbon on biostimulating crude oil polluted soil in the university of port-harcout by Chikere et. al., (2009) was observed. TPH decreased from $3666 \mathrm{mg} / \mathrm{kg}$ on pollution to $135.01 \mathrm{mg} / \mathrm{kg}$ (with poultry manure) and $89.68 \mathrm{mg} / \mathrm{kg}$ (with N.P.K fertilizer) after treatment for 157 days.

The general reduction in the Total Hydrocarbon Content could be attributed to the ability of the particulates and fertilizer to foster the growth of micro organisms (biostimulation), which in turn feed on the hydrocarbons. The lower aged particles returned a better result in conformity to the growth curve of micro organisms, which after the growth and stationary period, the death phase sets in. Hence, while the lower aged particles will be harbouring organisms that are still in their growth phase, the older ones will have organisms in their stationary or death phase, leading to lower degradation rate as competition, age, lack of nutrient would have led to the decline in microbial population. This also explains why samples $\mathrm{C}$ and $\mathrm{D}$ initially did better. In thiswork, sample C returned a slightly lower THC value than that of sample B, this was a deviation from the trend. This deviation could be due to the fact that the sample B compartment received more heat from the sun, this could have led to a decrease in moisture content which invariably reduces the number of microorganisms in that compartment. The heat also makes it difficult for the mesophillic bacteria, (which is mainly responsible for the degradation of petroleum hydrocarbon) to perform properly, limiting its habitat to only the cooler part of compartment C; this is as suggested by Nester et al., (2001) and Perfumo et al., (2007).

It was also observed that the highest decrease in Total Hydrocarbon Content occurred between week 0 and week 1; this was at the point at which the amendments were initially added, after acclimatization had occurred, this was probably because the micro organisms just entered their exponential growth phase. The addition of NPK fertilizer also enhanced the hydrocarbon degradation (Palmroth et al., 2006). This is supported from the above that moderate fertilizer must be used for better THC degradation.

The decrease in THC from the time the amendments were added to the end of the 8 weeks bioremediation process was very high from a mean value of 83.6 to $1.3 \mathrm{mg} / \mathrm{kg}(98 \%$ decrease). This was below the crictical level of $10 \mathrm{mg} / \mathrm{l}$ (FEPA) or 50mg/kg (Department of Petroleum Resources, 2002).

\subsection{Total Microbial Count (cfu/g) X $10^{6}$}

Table 8: Total Microbial Count of Crude Oil Contaminated Soil Bioremediated with Poultry Manure of Different Ages.

\begin{tabular}{|c|c|c|c|c|c|c|c|c|c|c|}
\hline \multirow{2}{*}{ SAMPLE } & AGE OF & \multicolumn{9}{|c|}{ TIME (WEEKS) } \\
\cline { 3 - 12 } & SAMPLE(DAYS) & 0 & 1 & 2 & 3 & 4 & 5 & 6 & 7 & 8 \\
\hline A & 3 & 1.5 & 1.8 & 1.9 & 2.2 & 2.5 & 2.4 & 2.6 & 2.8 & 3.0 \\
\hline B & 28 & 1.6 & 1.8 & 1.8 & 2.0 & 2.1 & 2.1 & 2.2 & 2.2 & 2.5 \\
\hline C & 42 & 1.6 & 1.9 & 1.9 & 2.1 & 2.2 & 2.3 & 2.3 & 2.4 & 2.6 \\
\hline D & 126 & 1.8 & 1.9 & 1.8 & 1.9 & 2.0 & 2.2 & 2.2 & 2.1 & 2.2 \\
\hline
\end{tabular}

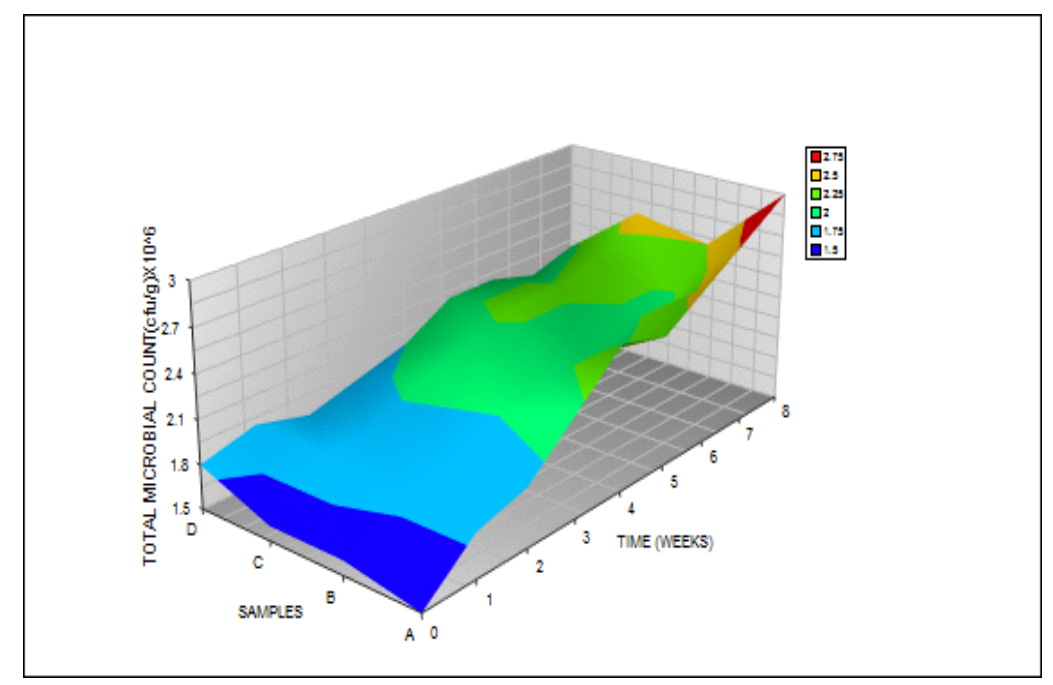

Figure 3: Variation of Total Microbial Count with Time and particulate age during the bioremediation process. 
Figure 3 is a plot of total micobial count as a function of time of bioremediation and age of particulate. A general increase in microbial population as well as a decrease with the age of particles was observed over the period of bioremediation.

This increasing trend of colony forming units is in agreement with that observed by Chikereet. al.(2009). In the study, the colony forming units of the heterotrophic bacteria of the crude oil polluted soil increased from $1.20 \times 10^{6} \mathrm{cfug}^{-1}$ to on amendment with $19.57 \mathrm{cfug}^{-1}$ poultry manure and $450 \mathrm{cfug}^{-1}$ on

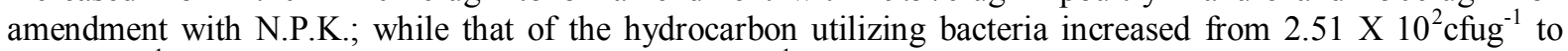
$0.257 \mathrm{cfug}^{-1}$ on treating with poultry manure and $38 \mathrm{cfug}^{-1}$ with N.P.K fertilizer.

Nwandinigwe and Onyeidu, (2012), observed same trend when crude oil contaminated soil was bioaugumented with pseudomonas and bacillus; and also treated with poultry manure. Its effect monitored by the growth of soya bean. At the end of the experiment on the soil there was a remediative effect.

The result of this present study revealed that the 3days old particle amended series, from week 3 exhibited a continuous lead in the population of microbes, samples B, C then D followed suit in the order (i.e. A having the highest and D having the least each week), with D having $2.2 \times 10^{6} \mathrm{cfu} / \mathrm{g}$ and A having $3.0 \mathrm{X} 10^{6} \mathrm{cfu} / \mathrm{g}$ in the last week; thus, implying that fresher particles provide better breeding ground for microorganisms. As previously mentioned, this is in line with the growth curve of microorganisms.

The increase in microbial population was via biostimulation, being that the poultry waste and fertilizer provided nutrients for increased cell growth.

The growth in microbial population was also fostered by the crude oil as it served as carbon and energy source as asserted by Akpoveta et al., (2011).

The range of $\mathrm{pH}$ observed in the study contributed immensely as well, to the proper growth and reproduction of the microbes by providing the required conditions for mineralization of hydrocarbons since most bacteria capable of metabolizing hydrocarbons develop best at $\mathrm{pH}$ close to neutrality (Mckee and Mendelssohn, 1995); and bacteria and fungi seems to be the microbes in this case. Bacteria has high capacity to degrade petroleum hydrocarbon, Xu, (2012),reported that it had a much higher hydrocarbon degradation rate when compared to other microbes. Also nutrients such as nitrogen and phosphorus are readily available in soil of $\mathrm{pH}$ range centered around 6.5 (Bickelhaupt, 2013).

The adequate supply of water to the soil aided the cell growth and function of the microorganism, by controlling the diffusion of water and soluble nutrients into and out of microorganism cells. However, excess moisture, such as in saturated soil, reduces the amount of available oxygen for aerobic respiration, hence making anaerobic respiration (which produces less energy for microbes and slows the rate of biodegradation), the predominant process. Soil moisture content between 45 and 85 percent of the water-holding capacity (field capacity) of the soil or about 12 percent to 30 percent by weight is optimal for petroleum hydrocarbon degradation (US EPA, 2006).

In all, the biodegradation rate was collectively enhanced by temperature, moisture, oxygen level, nutrients $\mathrm{pH}$, presence of microorganisms, etc. The above listed parameters could negatively affect the rate of degradation as well if not properly managed (Baba et al., 1998).

\section{Conclusion And Recommendations}

\subsection{Conclusion}

Inorganic fertilizers and poultry manure particles of different ages can significantly reduce the level of hydrocarbons in the soils to tolerable limits as observed in this study. The parameters with which the process was monitored were pH, Total Hydrocarbon Content (THC) and Total Microbial Count (TMC). At the end of the eight weeks bioremediation period, a biodegradation rate of $10.45 \mathrm{mg} / \mathrm{kgwk}, 10.16 \mathrm{mg} / \mathrm{kgwk}, 10.38$ $\mathrm{mg} / \mathrm{kgwk}$ and $10.19 \mathrm{mg} / \mathrm{kgwk}$ was computed for samples A,B,C and D respectively. It is therefore safe to conclude that lower aged poultry particles perform better than the older ones, in that they yielded a higher biodegradation rate.

\subsection{Recommendations}

There is prospect in utilizing the biological waste obtained from poultry birds in time, industrially, to ameliorate the menace left from oil spillage occurrences on land by contravening bodies. This method is environmentally friendly as it degrades the hydrocarbon present in the soil to less toxic substances.

Indigenous farmers can easily procure and utilize early aged particles in rectifying the condition of the soil if contaminated with crude oil. 


\section{References}

[1]. Agbogidi, O.M. (2011): Effects of Crude Oil Contaminated Soil on Biomass Accumulation in JatrophaCurcas L. Seedlings. Journal of Ornamental and Horticultural Plants 1 (1) $43-49$.

[2]. Adams, P.J. (1996): Bioremediation of oil spills: Theory and Practice. Proceedings of the $8^{\text {th. }}$ Biennial International NNPC Seminar. In: The Petroleum Industry and the Nigeria Environment, Port Harcourt, Nigeria, 183-203.

[3]. Akpoveta O., Egharevba F., Medjor O., Osaro K. and Enyemike E. (2011): Microbial Degradation and its Kinetics on Crude Oil Polluted Soil. Research Journal of Chemical Sciences, Vol. 1(6), 8-14.

[4]. American Petroleum Institute Information Bulletin, (1958) No 11, Philadelphia Pa.

[5]. Ayotamuno M.J., Olatunji O.M., Ikari S.T.(2013): Petroleum Contaminated Soil Remediation Using Poultry Feaces and Plantain Stem. International Journal of Scientific \& Engineering Research Volume 4, Issue3.

[6]. Baruah, D., Das N.J. (1994): Industrial pollution control, 10 (2) 139-44.

[7]. Benyahia F., Abdulkarim M., Zekri A., Chaalal O. and Hassan H. (2005): Bioremediation of Crude Oil Contaminated Soils; A Black Art Or An Engineering Challenge? Trans IChemE Part B, Process Safety and Environmental Protection, 83 (B4) $364-70$.

[8]. Bickelhaupt, D. (2013): Soil pH: what it means. Environmental Information Series.

[9]. Black, C.A. (1957): Soil Plant Relationship. John Wiley and Sons. Inc., New York.

[10]. Boopathy, R. (2000): Factors Limiting Bioremediation Technologies. Bioresource Technology 74, pp63 -67

[11]. Brian, K. (1977): Soil Processes. $1^{\text {st }}$ Edition. Allen George Unwin. London.

[12]. Braun, Robert, L., Burnham, lan, K. (June 1993): Chemical Reaction Model for Oil and Gas Generation from Type I and Type II Kerogen. Lawrence Livermore National Laboratory.

[13]. Chikere, C.B., Okpokwasili, G.C. and Chikere B.O. (2009):Bacterial diversity in a tropical crude oil-polluted soil undergoing bioremediationAfrican Journal of Biotechnology Vol. 8 (11), pp. 2535-2540.

[14]. Clarkson, D.T., Hanson, J.B., Ann Rev (1980): Plant Physiol. 31: 239-98.

[15]. D'el Arco j.p. and franca f.p. (1999): Biodegradation of crude oil in sandy sediment. International biodeterioration and biodegradation 44:87-92.

[16]. Department Of Petroleum Resources, DPR (1991): Environmental Guidelines and Standards for the Petroleum Industry in Nigeria. Department of Petroleum Resources, Ministry of Petroleum and Mineral Resources, Lagos, Nigeria.

[17]. Domask, W. G. (1984). Introduction to petroleum hydrocarbons. Chemistry and composition in relation to petroleum derived fuels and solvents. Effects of petroleum hydrocarbons. Adv. Nod. Environ. Tox. 8: 1-26.

[18]. Ebere, J.U., Wokoma, E.C. and Wokocha, C.C. (2011): Enhanced Remediation of a Hydrocarbon Polluted Soil. Research Journal of Environmental and Earth Sciences 3 (2) 70-74.

[19]. Edwards, D.R., and Daniel, T.C. (1992): Environmental impacts of on-farm poultry waste disposal-A review. Bioresource Technology 41:9-33.

[20]. Ellis, R., Adams, R.S. (1961): Contamination of Soil by Petroleum Hydrocarbons. Advanced Agronomy, Vol. $13,197-216$.

[21]. Eneje R.C., Nwagbara C., and Uwumarongie-Ilori E.G. (2012): Amelioration of chemical properties of crude oil contaminated soil using Compost from Calapoigoniummucunoidesand poultry manure.International Research Journal of Agricultural Science and Soil Science Vol. 2(6) pp. 246-251.

[22]. Essien, O.E., and John I.A. (2010): Impact of Crude-Oil Spillage Pollution and Chemical Remediation on Agricultural Soil Properties and Crop Growth. Journal of Applied Science and Environmental Management, Volume 14 (4), $147-154$.

[23]. Federal Environmental Protection Agency (FEPA) (1997): Guidelines and Standards for Environmental Impact Assessment in Nigeria, pp. 87-95.

[24]. Gary, J.H. and Handwerk, G.E. (2001): Petroleum Refining and Technology and Economics, fourth edition, Marcel Dekker, Inc. pages 21-35.

[25]. Gruse, W.A and Stevens, D.R. (1960): Chemical Technology of Petroleum, 3rd Edition, McGraw-Hill Book Company, New York, pp. 424-472.

[26]. $\quad$ http://www.opec.org/pressroom/FAQ/crudeoil

[27]. Mckee, K.G. and Mendelssohn, I.A., (1995): A review of the methods of ecological consequences of substrate aeration for the enhancement of oil bioremediation in wetland. Report to the Marine Spill Response Corporation.

[28]. Nester, M.T., Eugene, W., Denise, G.A., Roberts, C.E., Pearsall N.N., (2001):Microbiology: A Human Perspective. 3rd ed. New York: McGraw-Hill.

[29]. Nwadinigwe, A.O., Onyeidu, E.G. (2012): Bioremediation of Crude Oil-Polluted Soil Using Bacteria and Poultry Manure Monitored through Soybean Productivity. Pol. J. Environ. Stud. 21 (1) 171-176.

[30]. Nwilo, P.C., Badejo, O.T. (2001): Impacts of Oil Spills Along The Nigerian Coast. The Association for Environmental Health and Services.

[31]. Obahiagbon, K.O., Akhabue, C.E., Aluyor, E.O. (2009): Effect of varying concentration of sodium nitrate on biological oxidation of petroleum hydrocarbon polluted water. Journal of Engineering and Technology Research, 1(3): 50-55.

[32]. Obahiagbon, K.O., and Audu T.O.K. (2002): Analysia of biodegradation rate of crude oil contaminated soil using fertilizer or cow dung.Nigerian Journal of Environmental Research and Development 1(1).

[33]. Odu, E.A. (1987): Impact of Pollution in Biological Resources Within The Niger Delta. Technical Report on Environmental Pollution Monitoring of the Niger Delta Basin of Nigeria. Environmental Consultancy Group, University Of Ife 6: 69-121.

[34]. Odu, C.T.I., Amadi, E.N., Okolo, J.C. (2005): Effect of soil treatments containing poultry manure on crude oil degradation in a sandy loam soil. Applied Ecological Environ. Res 3 (1) 47.

[35]. Okeimen C.O and Okeimen F.E. (2005): Bioremediation of Crude Oil-Polluted Soil- Effect of Poultry Droppings and Natural Rubber Processing Sludge Application on Biodegradation of Petroleum Hydrocarbons. Environmental Sciences, MY Tokyo, 12 (1) $1-8$.

[36]. Onwurah, I. N. E. (1999): Restoring the crop sustaining potential of crude oil polluted soil by means of Azotobacter inoculation. Plant Prod. Res, Journal 4: 6-16.

[37]. Onwurah, I.N.E., Ogugua, V.N., Onyike, N.B., Ochonogor, A.E. and Otitoju, O.F. (2007): Crude Oil Spills in the Environment, Effects and Some Innovative Clean-Up Biotechnologies, International Journal of Environmental Research 1 (4) 307-320.

[38]. Perfumo A., Ibrahim M.B., Roger M., Luigi V., (2007): Thermally Enhanced Approaches for Bioremediation of HydrocarbonContaminated Soils. Chemosphere 66:179-184.

[39]. Ronen, E. (2007):Micro-elements in Agriculture. Practical Hydroponics and Greenness. 39-45

[40]. Schnoor, J. L., Licht, L. A., McCutcheon, S. C., Wolfe, N. L., Carreira, L. H., (1995): Phytoremediation of organic and nutrient contaminants. Environ. Sci. Technol., 29 (7), 318A-323A. 
[41]. Tanee, F.B.G., Albert, E. (2011): Biostimulation Potential Of Sawdust on Soil Parameters And Cassava (ManihotEsculenta; Crantz) yields in Crude Oil Polluted Tropical Soil. Advances in Environmental Biology.

[42]. Tanee, F.B.G., Akonye, L.A. (2009): Phytoremediation potential of Vignaunguiculata in a crude oil polluted tropical soil of the Niger-Delta. Global Journal of Pure and Applied Sciences, 15 (1) 1-4.

[43]. Tang, J., Wang, R., Niu, X., Wang, M., and Zhou Q. (2010): Characterization on the rhizoremediation of petroleum contaminated soil as affected by different influencing factors. Biogeosciences Discuss., 7: 4665-4688.

[44]. Timmis, K.N., Pieper, D.H. (1999). Bacteria designed for bioremediation. Trends Biotechnology 17: 201-4.

[45]. Udo, E.J., Fayemi, J. (1975): the effect of pollution on germination and nutrient uptake of corn. J. Environ. Qual. 4: 537-40.

[46]. United States Department of Agriculture, Natural Resources Conservation Services (2004): Use of Reaction (pH) In Soil Taxonomy. Soil Survey Laboratory Methods Manual, Version No. 4. Soil Survey Investigations Report No 42.

[47]. US environmental Protection Agency, 2006.Landfarming .

[48]. Wallace, T. (1951): Trace elements, in plant, physiology. International Union of Biological Sciences.Colloquia, No. 1, series B. 5-9.

[49]. Xu J. (2012): Introduction to Enhanced Oil Recovery (EOR) Processes and Bioremediation of Oil-Contaminated Sites. Intech publishers.Pages 207-244.

[50]. Yehuda, C. (2002): Bioremediation of oil by marine microbial mats. Int. Microbial 5: 189-93. 